\title{
SCHOOL OF
}

\section{CIVIL ENGINEERING}

\section{INDIANA}

\section{DEPARTMENT OF TRANSPORTATION}
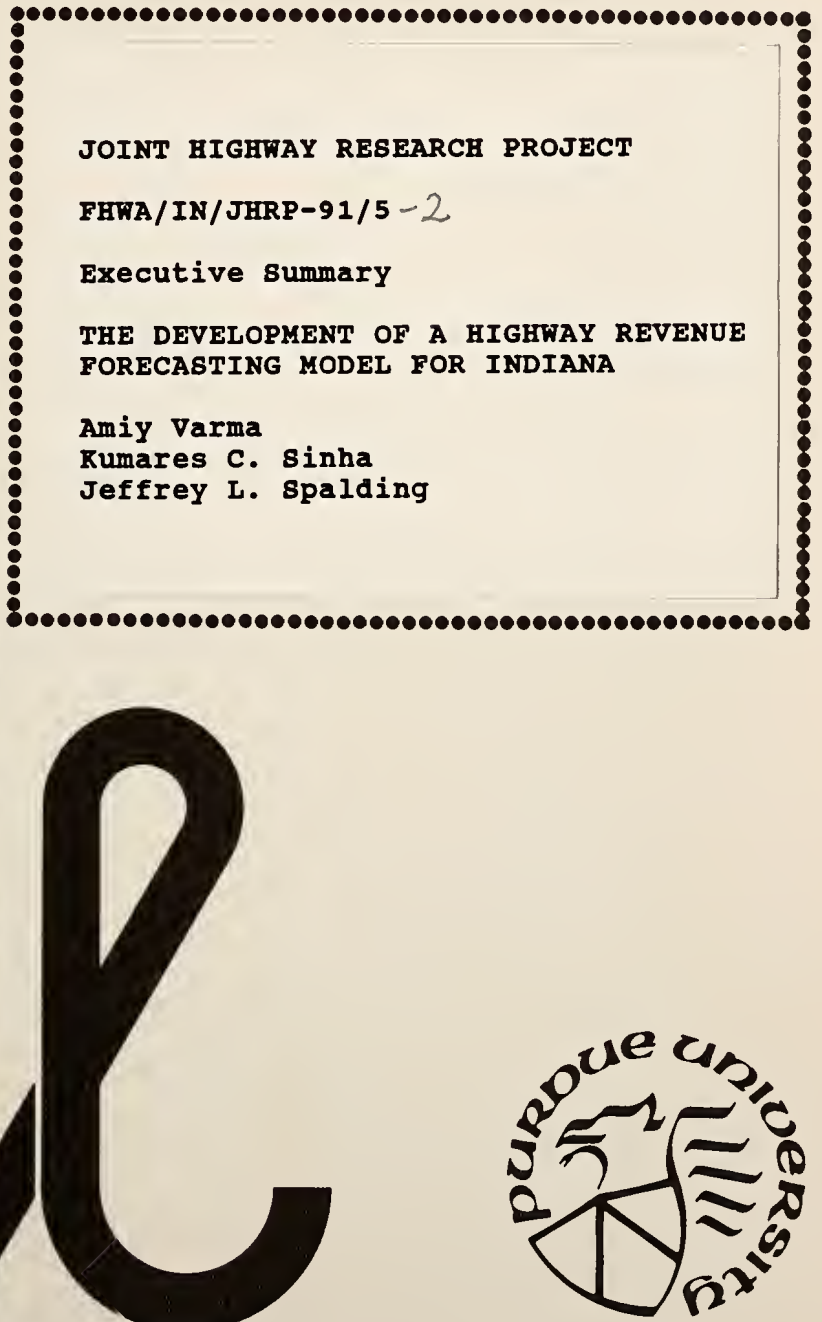


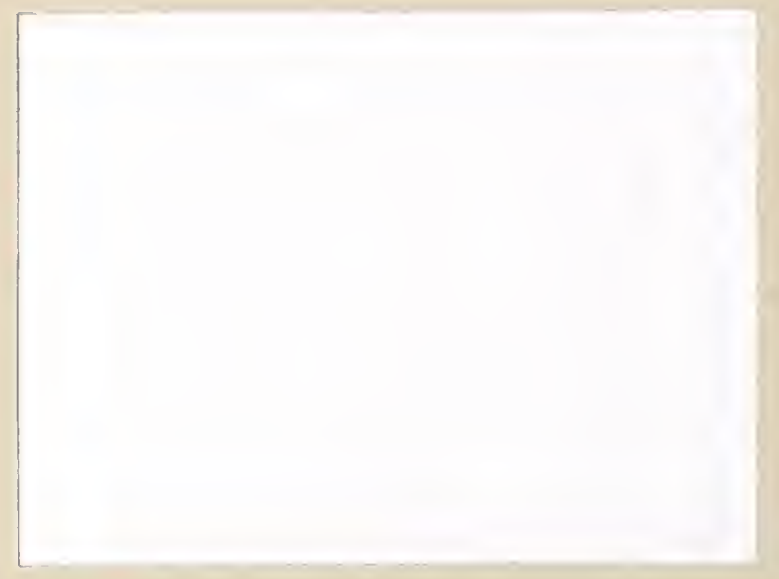


JOINT HIGHWAY RESEARCH PROJECT

FHTA/IN/JHRP-91/5-2

Executive summary

THE DEVELOPMENT OF A HIGHWAY REVENUE FORECASTING MODEL FOR INDIANA

Amiy Varma

Kumares C. Sinha

Jeffrey I. Spalding 

The Development of a Highway Revenue Forecasting Model

$$
\text { for Indiana }
$$

\section{Executive Summary}

TO: Vincent P. Drnevich, Director Joint Highway Research Project

January 8, 1991

Revised January 22, 1992 Project: $c-36-73 \mathrm{~J}$

FROM: Kumares C. Sinha, Associate Director Joint Highway Research Project

File: $3-4-11$

Attached is the Final Report on the HPR Part I study titled, "The Development of a Highway Revenue Forecasting Model for Indiana." This report presents the forecasts of highway revenues for Indiana under various scenarios and details the operation of a computer model developed for the same. This research was conducted by Amiy Varma under my direction.

This report is forwarded for review, comment and acceptance by the INDOT and FHWA as fulfillment of the objectives of the study.

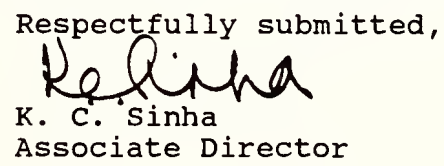

A. G. Altschaeffl

D. Andrewski

P. L. Bourdeau

M. D. Bowman

M. J. Cassidy

L. M. Chang

S. Diamond

J. J. Dillon

W. L. Dolch

v. P. Drnevich
A. R. Fendrick

J. D. Fricker

D. W. Halpin

K. R. Hoover

R. H. Lee

C. W. Lovell

R. H. Lowry

D. W. Lucas

B. G. McCullouch

B. K. Partridge

J. A. Ramirez
G. J. Rorbakken

C. F. Scholer

G. B. Shoener

K. C. Sinha

D. L. Tolbert

C. A. Venable

T. D. White

L. E. Wood

J. R. Wright

R. F. Wukasch 
The Development of a Highway Revenue Forecasting Model for Indiana

Executive Summary

Amiy Varma

Graduate Research Assistant

Kumares C. Sinha

Professor of Civil Engineering

and

Jeffrey L. Spalding

Indiana Department of Transportation

Joint Highway Research Project

Project No.: c-36-73J

File No.: $3-4-11$

Prepared as Part of an Investigation

conducted by

Joint Highway Research Project

Engineering Experiment station

Purdue University

in cooperation with the

Indiana Department of Transportation

and the

U.S. Department of Transportation

Federal Highway Administration

\author{
Purdue University \\ West Lafayette, IN 47907 \\ January 8, 1991 \\ Revised January 22, 1992
}


Digitized by the Internet Archive in 2011 with funding from

LYRASIS members and Sloan Foundation; Indiana Department of Transportation 
TECHNICAL REPURT STANIIARU TITLE EACE

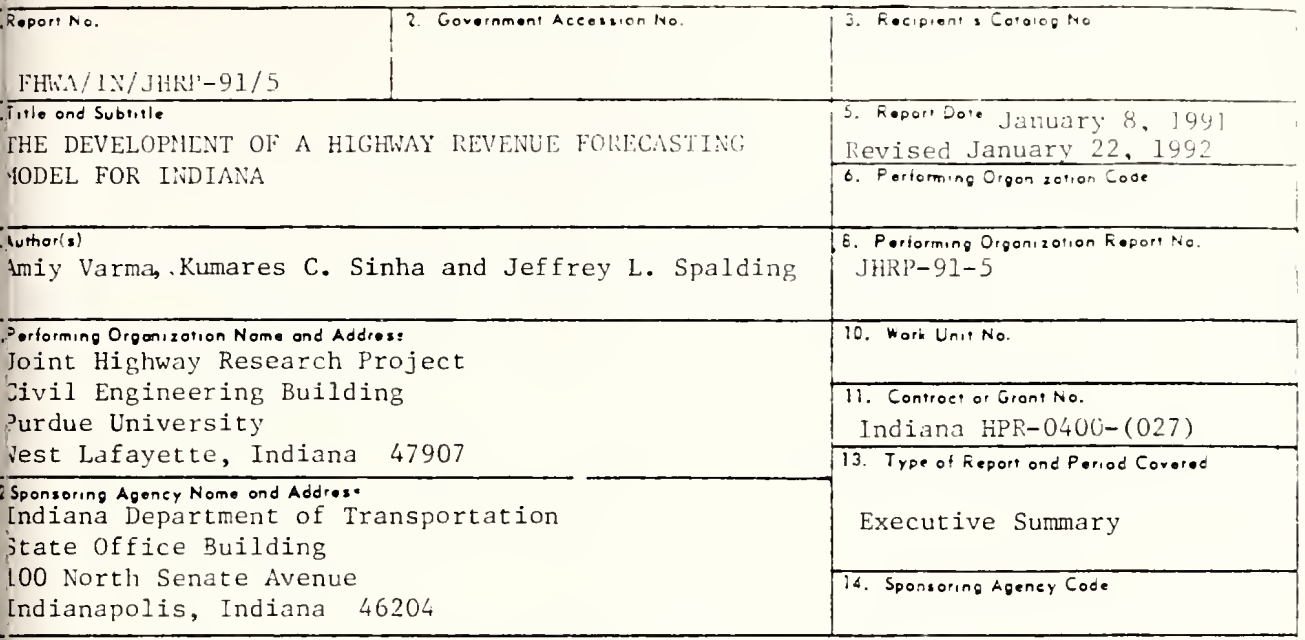

Supolementory Notes

Prepared in cooperation with the U.S. Department of Transportation, Gederal Highway Administration on HPR Part I Study "The Development of a Highway Revenue Forecasting Model for Indiana".

This report present a state highway revenue forecasting model developul for Indiana Department of Transportation. The package provides both long range annual forecasts as well as short range monthly foreasts of highway revenues by source. An important feature of the model is its ability tn adopt new parameters and input data in orier to avoid obsolescence. The nodel can be used to determine expected amounts of revenues under existing taxaticn structures as well as to assess impacts of possible changes.

\begin{tabular}{|c|c|c|c|c|}
\hline \multirow{2}{*}{\multicolumn{2}{|c|}{$\begin{array}{l}\text { Koy wores } \\
\text { State Highway Revenue, Long Tern } \\
\text { Forecasts, Slont Term Forecasts, } \\
\text { iotor Fuel Taxes and Regist:alion }\end{array}$}} & \multirow{2}{*}{\multicolumn{3}{|c|}{ 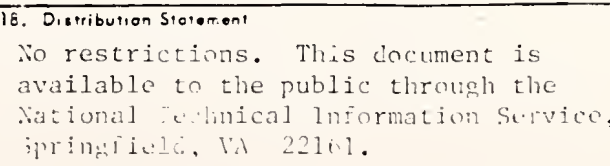 }} \\
\hline & & & & \\
\hline $\begin{array}{l}\text { Security Clossif lot this reportl } \\
\text { Indiassilied }\end{array}$ & \multicolumn{2}{|c|}{$\begin{array}{l}\alpha \text { Security Clossit. iot thicoogel } \\
\text { linc lassiti.ud }\end{array}$} & $\begin{array}{l}\text { 2i. No. of oges } \\
19\end{array}$ & 22. Pilce \\
\hline
\end{tabular}




\section{Introduction}

State transportation agencies are facing challenges arising from cost uncertainties resulting from economic instability; escalation of construction, maintenance, and operating costs; and erosion of revenues due to instability of some of the revenue bases, in particular motor fuel taxes, resulting from vehicular technological advancements. Proposed shifts in revenue sources from federal to state and local governments would further add to these challenges. Under such circumstances the agencies are realizing: (a) the need to develop and periodically update forecasts for a variety of revenue sources for planning and budgeting purposes; and (b) that they must do so under constraints of limited data, technical skills and budget resources.

The primary purpose of this study was to develop a computerized highway revenue forecasting model for the Indiana Department of Transportation (INDOT) which could provide both longterm and short-term forecast of highway revenues by source. An exhaustive literature review, extensive data collection, and analyses of revenue and travel-related data were conducted to develop the regression and other models which form the basis of the computerized system. The final system is responsive to socioeconomic, technological, and legislative policy changes.

\section{Indiana Highway Revenues and Their Disbursement}

Major sources of highway revenue are federal aid, motor fuel taxes, vehicle registration fees, driver license fees, and revenue 
bonds. For 199138 \% of INDOT's total highway revenues were from federal-aid and 2 from other miscellaneous sources. The remaining portion is made up of motor fuel taxes, vehicle registration fees, and driver license fees. In 1987, Indiana joined International Registration Plan (IRP) which was aimed at distributing fairly the registration fees paid by the long-haul heavy trucks (above 26,000 lbs and/or having more than two axles) among the different states whose highway facilities were used.

The distribution of highway revenues in Indiana center around two major accounts, the Motor Vehicle Highway Account (MVHA) and the Highway Road and street Fund (HRSF). Other revenue accounts include the Special Distribution (SD), state Highway Road construction \& Improvement Fund (SHCF), and the Motor Carrier Regulation Fund (MCRF). Highway revenues are distributed to these funds according to legislated ratios.

\section{Long-Term Highway Revenue Forecasting Methodology}

This study disaggregates total revenues into the revenues obtained from the six major sources--registration fees, driver licenses, gasoline tax, special fuel tax, diesel surtax, and motor carrier fuel use tax. The revenues from each source can be further separated into component parts (tax rate and revenue base). Figures 1 and 2 indicate the overall structure of how vehicle registration revenues are estimated. The overall procedure to obtain the annual VMT by different vehicle categories is shown in Figure 3. Fleet fuel efficiency is based on the consideration 


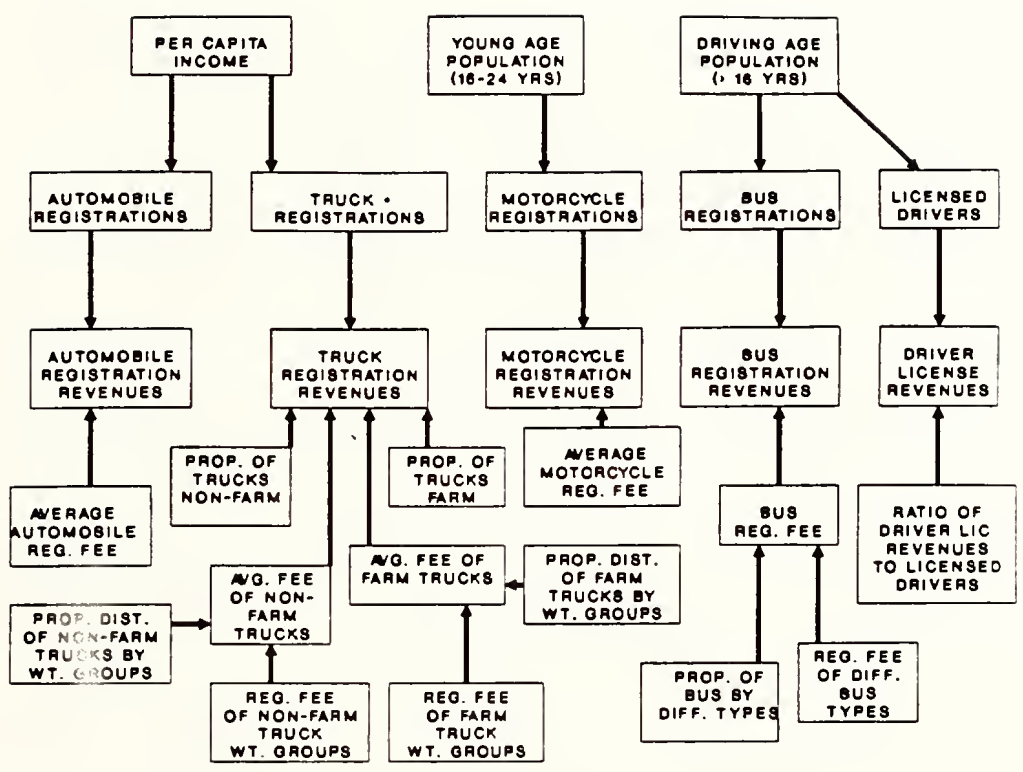

Figure 1. Overall Procedure to Compute Automobile, Truck, Bus, and Motorcycle Registration Revenues and Driver License Revenues 


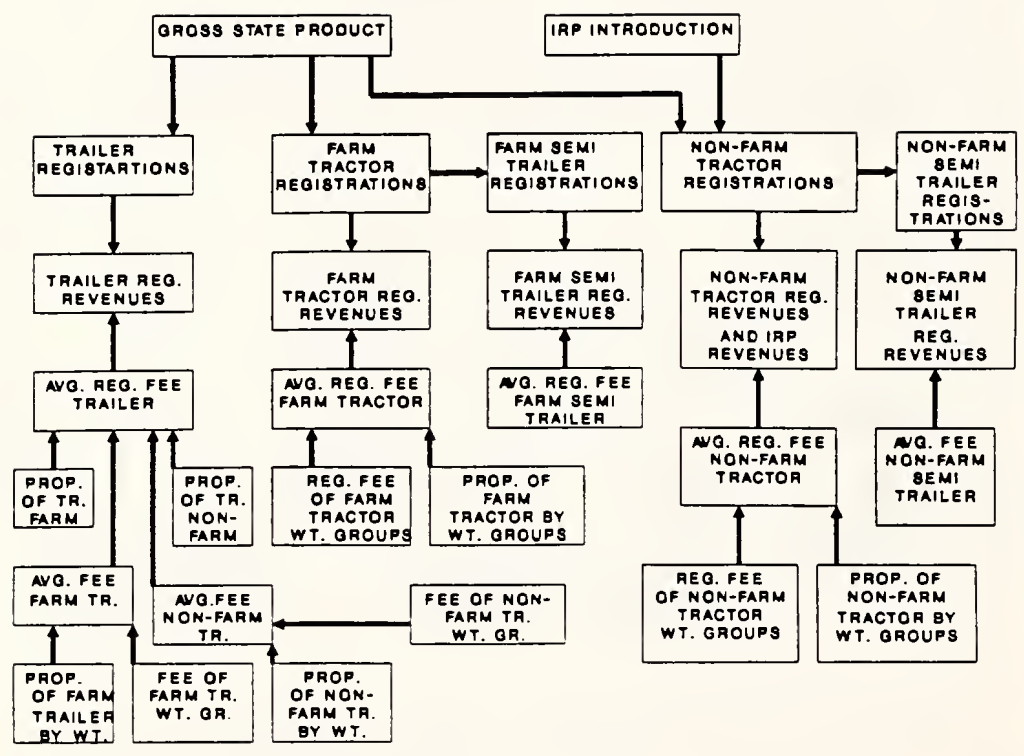

Figure 2. Overall Procedure to Compute Tractor, Trailer, and Semitrailer Registration Revenues 


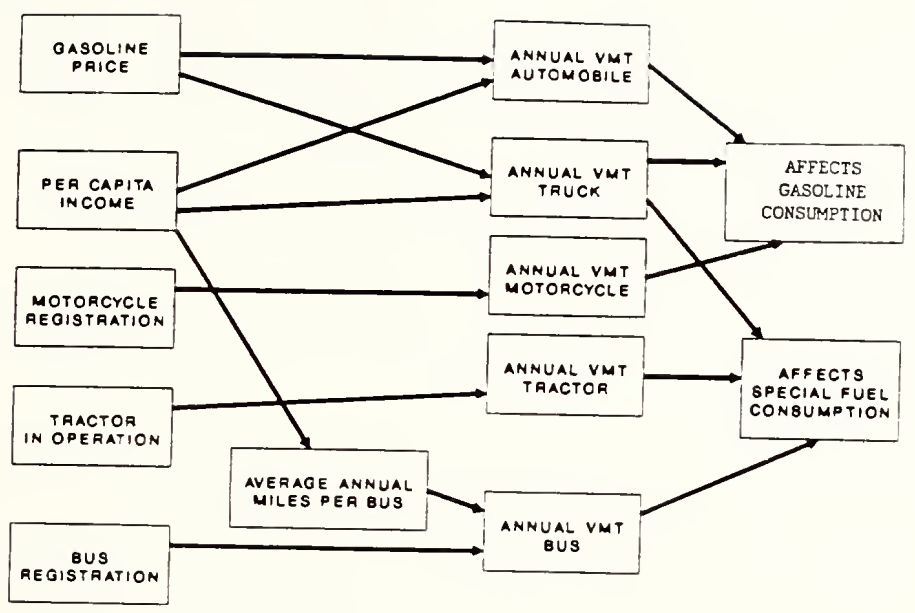

Figure 3. Overall Procedure to Compute Annual VMT by Different Vehicle Categories 
of vehicle sales and scrappage rates, and technological factors affecting the fuel efficiency of new vehicles. Figures 4,5 and 6 indicate the computational procedure for estimating fleet fuel efficiencies of automobiles, trucks, and tractors respectively. The fleet fuel efficiency of buses for the purpose of this study has been assumed to be same as that of tractors. The VMT and fleet fuel efficiencies are used to compute the fuel consumption. The overall structure for estimating motor fuel tax revenues is shown in Figure 7 .

The most widely used short-term forecasting method is the decomposition method. The basic aim in the decomposition method is to find the seasonality existent in the revenue or other data; and thus, distribute the annual forecast to monthly estimates using the seasonal factors computed. Such an approach has been adopted for determining the monthly forecasts in this study. Short-term forecasts are made using an alternative approach which uses: a) trend projections of the seasonally adjusted data; and b) the seasonal factors. The trend projections are made using time periods.

\section{Modeling}

Several linear regression, non-linear regression and other models were established for vehicle registrations, vehicle sales, vehicle scrappage, vehicle travel, and vehicle fleet fuel efficiency. Demographic data used in developing relationships were total population, driving age population (above 16 years old), 


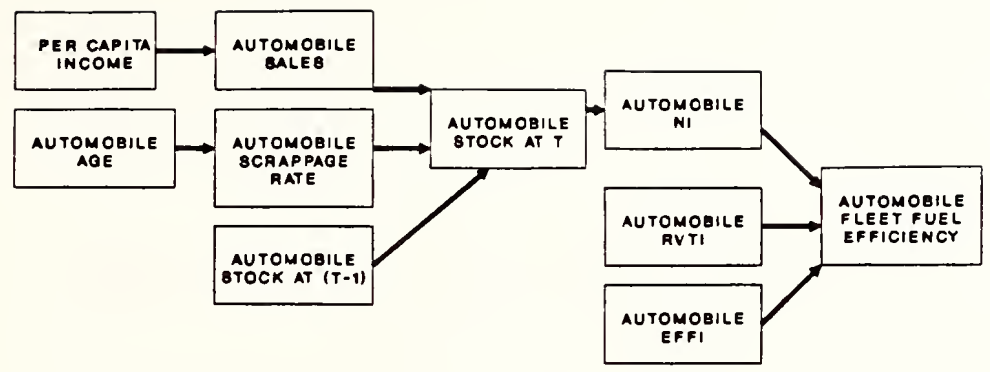

NOTE: NI IS PROPORTION OF AUTOMOBILE IN ITH AOE COHORT

RVTI IS RELATIVE VEHICLE USE OY AUTOMOBILE INITH AGE COHORT

EFFI IS THE FUEL EFFICIENCY OF AUTOMOBILE IN ITH AOE COMORT

Figure 4. Procedure to Compute Fleet Fuel Efficiency of Automobiles

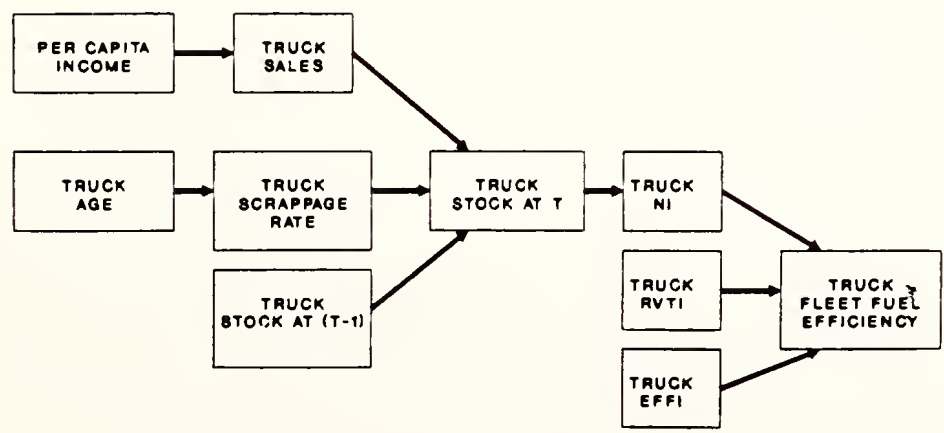

NOTE: NI 18 PROPORTION OF TRUCK IN ITH AOE COHORT

RVTI IS RELATIVE VEHICLE USE GY TRUCK IN ITH AOE COMORT

EFFI IS THE FUEL EFFICIENCY OF TRUCK IN ITH AOE COHORT

Figure 5. Procedure to Compute Fleet Fuel Efficiency of Trucks 


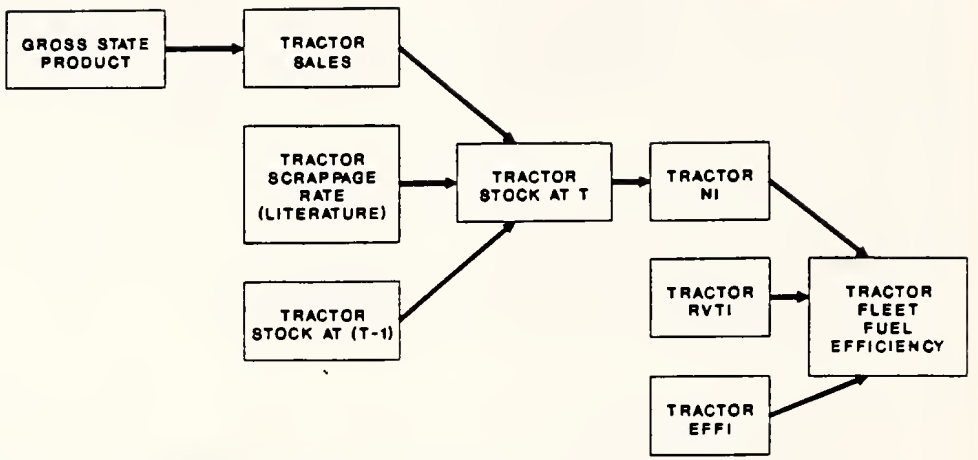

NOTE: NI IS PROPORTION OF TRACTOA IN ITH AOE COHORT

RVTI I8 RELATIVE VEHICLE USE BY TRACTOA IN ITH AOE COHORT

EFFI IS FUEL EFFICIENCY OF TAACTOR IN ITH AGE COMORT Figure 6. Procedure to Compute Fleet Fuel Efficiency
of Tractors 


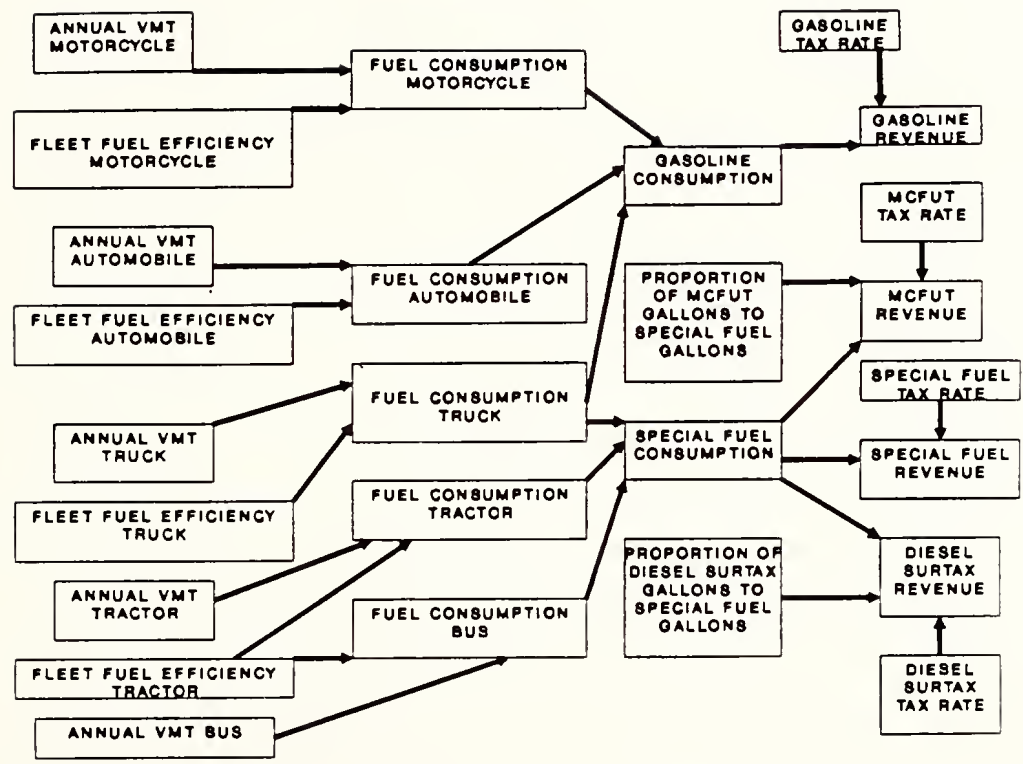

3

Figure 7. Overall Procedure to Compute Motor Fuel Tax Revenues 
young age population (population between 16 years and 25 years old), and less than driving age population (less than 16 years old). Economic variables used in this study are per capita income in 1982 dollars in Indiana, gross state product in thousands of 1982 dollars, national Consumer price Inflation (CPI) index, national Gross National Product (GNP) implict price deflator, and gasoline price in dollars. The established linear and non-linear regression relationships have $R^{2}$ (most above 0.80) and F-values (most above 3.0) indicating that the dependent variables correlate very well with independent variables, and that the independent variables are significant. These models are then integrated into a computerized program, INDOTREV, which uses an input file "DATA" to provide forecasts. The computerized model provides both short and long term forecasts and offers the users the ability to conduct sensitivity analyses. Being menu driven, the system is user friendly. The updating (which is most essential in any forecasting process) of the program can be performed by just updating the "DATA" file. The process of updating the "DATA" file is discussed in detail in Chapter 8 of this report. The flexibility of updating prevents the obsolescence of the model. As the new data becomes available the user can update both the relationships used and the input data through the "DATA" file. The SHORTREV program computes new seasonal factors and trend equations as the new data is entered in the files--GASIN (gasoline data file), SPFIN (special fuel data file), STAXIN (diesel surtax data file), MCFUTIN (motor carrier fuel use tax data file), REGIN (vehicle license fee data file), and 
IRPIN (IRP data file). The SHORTREV program provides forecasts for six months in future from the last month in the respective data files.

\section{Results}

Nearly all of the revenue estimations were within $5 \%$ error, and the total revenue estimation (without revenues from sources such as federal reimbursement, general funds, etc.) was within $1 \%$ error. Somewhat less reliable segments were the estimation of IRP revenues, Motor Carrier Fuel Use Tax (MCFUT) revenues and Diesel surtax revenues. Much of this had to do with the data limitations in studying the underlying phenomena behind the revenue generation from these sources. The forecasts of short-term gasoline and special fuel gallonage were within $10 \%$ error for most of the months. For other categories, MCFUT and diesel surtax the variability of short-term forecasts from observed values was much more than found in the other two motor fuel tax categories essentially due to inadequate data. The quarterly estimations obtained by the execution of the SHORTREV program were within $10 \%$ for all revenue sources except MCFUT and IRP. The long-term results indicate that overall highway revenues are going to increase 23.8 $\%$ in current dollars by the year 2005. For the same period, registration revenues (excluding IRP revenues) are going to increase by $31.3 \%$ in current dollars, gasoline revenues by $27.34 \%$, special fuel revenues, as well as MCFUT and motor carrier surtax revenues by $14.39 \%$. Thus we see that the revenues from vehicles 

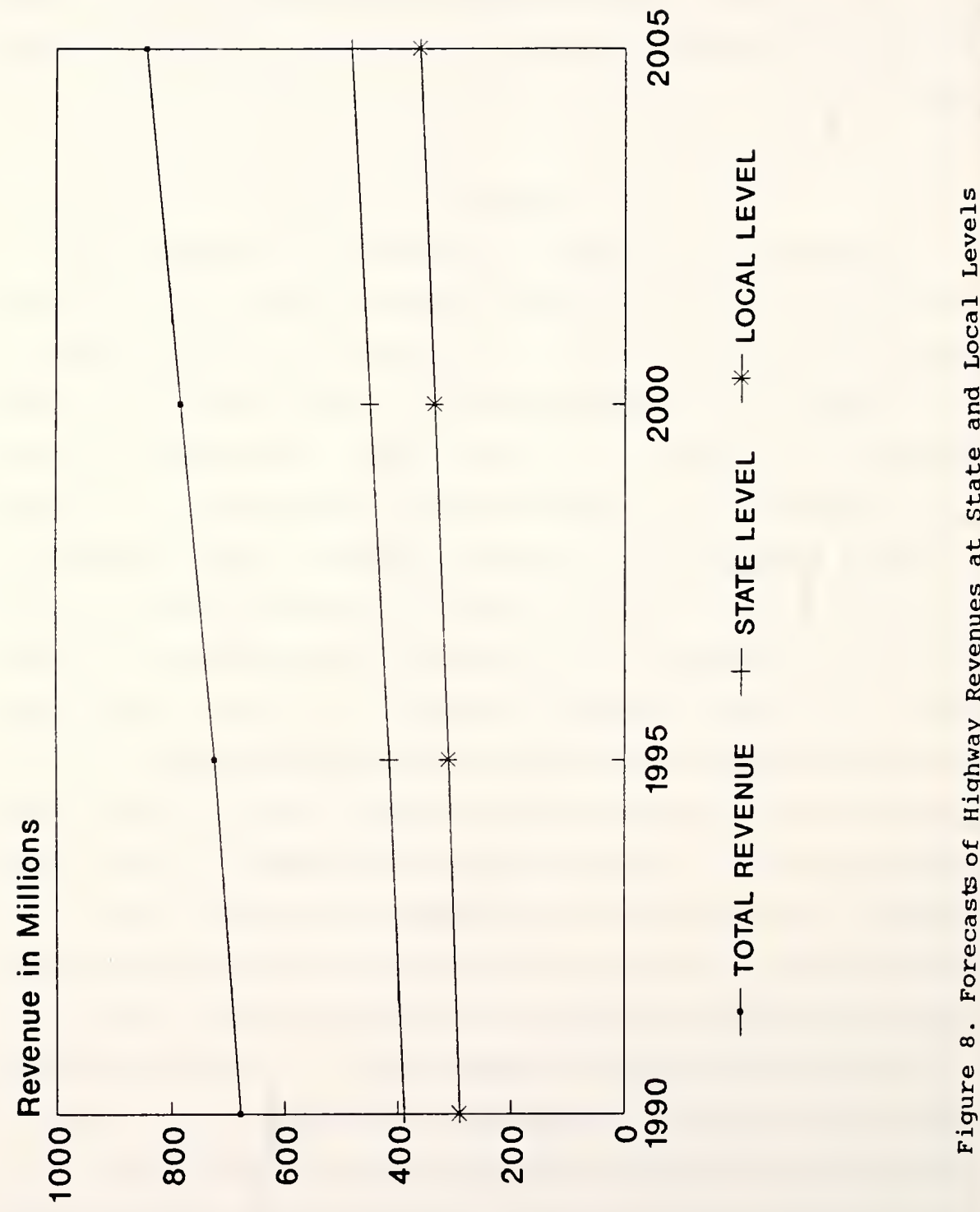


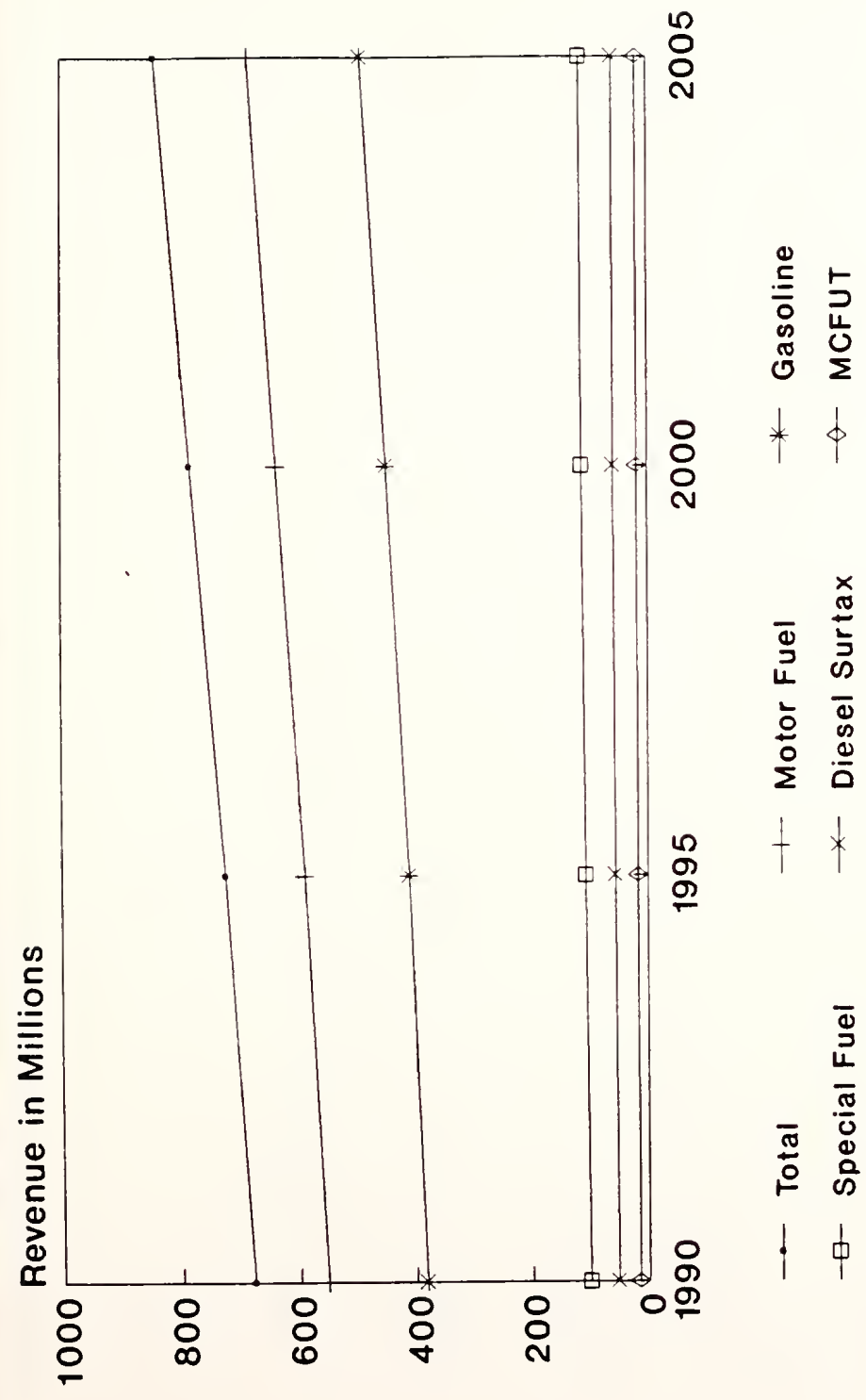

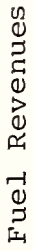

4
0
+

㟧

0
0
0
0
0
0
0
0

a

总 


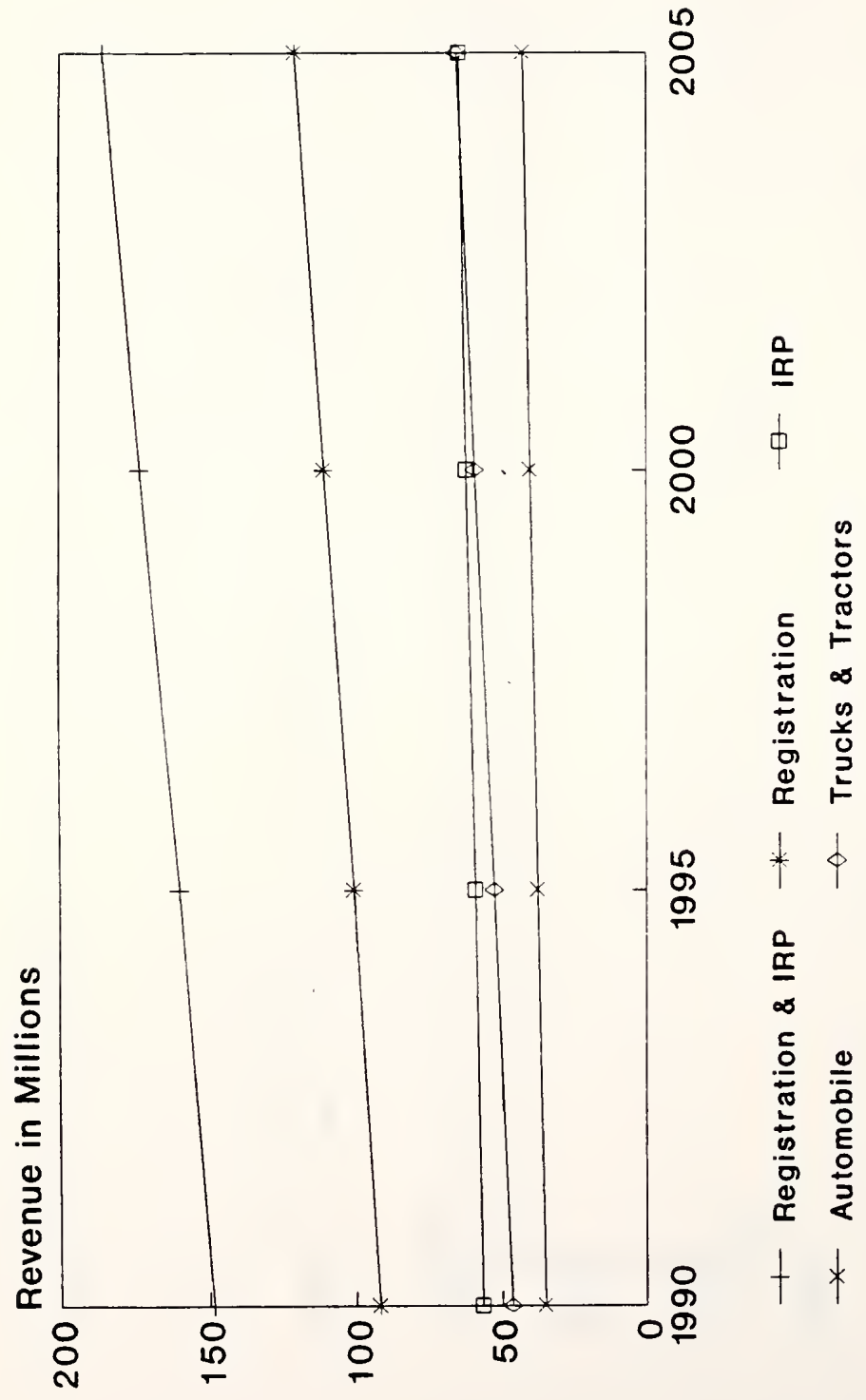

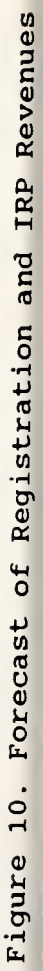


10
0
0

$$
\frac{U}{3}
$$

*

$\begin{array}{ll} & 4 \\ 0 & 0 \\ 0 & 1 \\ 0 & 1\end{array}$

羿

$\frac{\pi}{ \pm}$

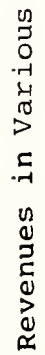

오

$\frac{4}{\infty}$

$t$

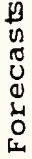

$\underset{1}{*}$

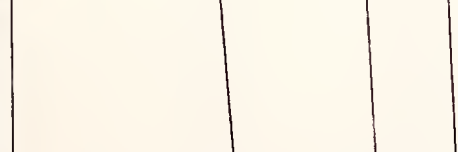

$\mid>1$

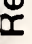

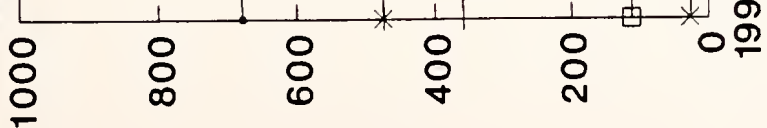

ปุ. 
contributing the most damage to the facilities is going to increase the least. Total state highway revenues will reach about $\$ 843.2$ million in 2005. Figure 8 indicates the forecast of highway revenues at state and local levels. Forecasts of motor fuel highway revenues are shown in Figure 9. Forecasts of registration and IRP revenues are shown in Figure 10. Figure 11 indicates revenue forecasts for the various funds in future.

Short-term highway revenue forecasts for the years 1991 and 1992 as obtained by executing INDOTREV program are shown in Table 1 of this report. The short-term results obtained by executing SHORTREV program are shown in Tables 2 and 3 . The effects of increasing the tax rates for different revenue sources as of 1991 are presented in Table 4. A penny increase in gasoline tax can generate more than $\$ 25$ million; whereas, the same increase in special fuel tax fetches only additional $\$ 6.3$ million. An increase in the automobile registration fee of $\$ 1$ produces a revenue increase almost 90 times that resulting from increasing the registration fee of non-farm tractors above 78,000 lbs by $\$ 5$. 
Table 2. Validation of Forecasts from "SHORTREV"

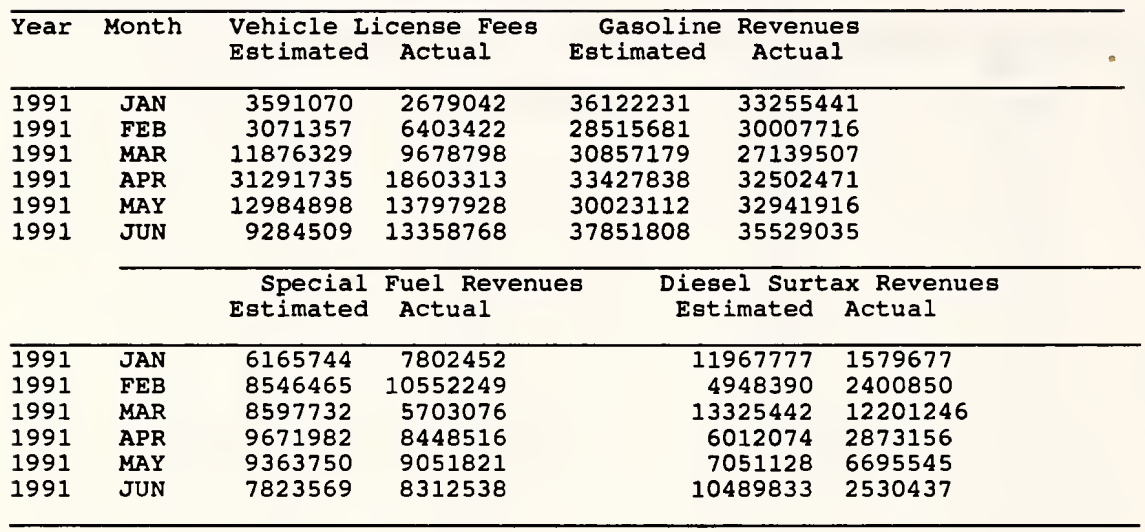

Table 3. Short-Term Forecasts Using "SHORTREV"

\begin{tabular}{lcrc}
\hline Year & Month & Vehicle License Fees & Gasoline Revenues \\
\hline 1991 & JUL & 12674607 & 36359952 \\
1991 & AUG & 9496767 & 35745766 \\
1991 & SEP & 10229339 & 36171900 \\
1991 & OCT & 7987542 & 34330813 \\
1991 & NOV & 9121820 & 34595754 \\
1991 & DEC & 7366113 & 31946918 \\
\multicolumn{1}{r}{} & & \\
\cline { 2 - 4 } & & Specia1 Fuel Revenues & Diesel Surtax Revenues \\
1991 & JUL & 10065615 & 1950959 \\
1991 & AUG & 8993414 & 6895776 \\
1991 & SEP & 8949771 & 6711283 \\
1991 & OCT & 8542809 & 5678632 \\
1991 & NOV & 10489610 & 10183585 \\
1991 & DEC & 8689893 & \\
& & &
\end{tabular}


Table 4. Effects of Tax Rate Increases on Revenues Generated, 1991

\begin{tabular}{llc}
\hline Major Parameter & Action & $\begin{array}{c}\text { Effect on Revenue Generated } \\
\text { (Increase in 1000s of \$) }\end{array}$ \\
\hline $\begin{array}{l}\text { Gasoline Tax } \\
\text { Special Fuel Tax }\end{array}$ & Increase by 1 cent & 25114 \\
$\begin{array}{l}\text { Diesel Surtax } \\
\begin{array}{l}\text { Automobile Regis- } \\
\text { tration fee }\end{array}\end{array}$ & Increase by 1 cent & 6321 \\
$\begin{array}{l}\text { Registration fees } \\
\text { of Non-Farm } \\
\text { Tractors }>78,000 \text { lb }\end{array}$ & Increase by \$ 5 & 4445 \\
\end{tabular}

